\title{
Assessment of the agro-morphological variations in bread wheat genotypes under field conditions
}

\author{
Akhtiar Ahmed Kalhoro ${ }^{1}$, Hadi Bux Bozdar ${ }^{2}$, Hakim Ali Sahito ${ }^{1 *}$ \\ Tasneem Kousar ${ }^{1}$, Wali Muhammad Mangrio ${ }^{1}$ and Muhammad Aslam \\ Korai $^{1}$ \\ 1. Faculty of Natural Sciences, Shah Abdul Latif University, Khairpur Mir's, Sindh, Pakistan \\ 2. Institute of Plan Sciences, University of Sindh, Jamshoro, Sindh, Pakistan \\ *Corresponding author's email: hakim.sahito@salu.edu.pk
}

Citation

Akhtiar Ahmed Kalhoro, Hadi Bux Bozdar, Hakim Ali Sahito, Tasneem Kousar, Wali Muhammad Mangrio and Muhammad Aslam Korai. Assessment of the agro-morphological variations in bread wheat genotypes under field conditions. Pure and Applied Biology. Vol. 11, Issue 3, pp778-792. http://dx.doi.org/10.19045/bspab.2022.110079

\begin{tabular}{llll}
\hline \hline Received: 08/09/2021 & Revised: 13/11/2021 & Accepted: 17/11/2021 & Online First: 19/11/2021 \\
\hline
\end{tabular}

\section{Abstract}

The agro-morphological traits of seven bread wheat genotypes were assessed 4 genotypes were collected from International Wheat and Maize Improvement Centre Mexico, 2 from Nuclear Institute of Agriculture Tandojam, and 1 from Wheat Research Institute Sakrand, based on (RBCD) with 3 replications. The results indicated the number of grains/spikes were 41.29-70.29 grains with mean $54.02 \pm 4.42$ and 0.20 coefficient variance. The grain yield/spikes were 1.88-3.54 grams with mean $2.75 \pm 0.23$ at 0.21 coefficient variance with grain yield/plant were 5.05-20.51 grams with mean of $12.24 \pm 2.38$ were obtained. The maximum 14.02 grams, grain yield/plant were recorded in ESWYT-104 and 14.20 grams in ESWYT-123, while minimum 8.44 grams in SKD-1 genotype. The maximum plant height was 97.66 centimeters in ESWYT-104 and minimum 77 centimeters in SKD-1. The ESWYT-136 produced maximum 66.33 while; genotype SKD-1 minimum of 40.33 grains/spike. The grains/spike showed positive with significant correlation in grain yield/spike 0.97 days for maturity and plant height 0.91 . The grain yield/meter with positively non-significant correlation in grain yield/spike 0.16 , grain yield/plant 0.00 , and 100 -grain weight 0.07 . The plant height with negative, non-significant correlation to peduncle length -0.00 , the number of tillers/meter -0.00 , ten grains length -0.71 , and harvest index -0.42 . The analysis of variance showed significant and highly significant variations for agro-morphological traits in booting, flowering, heading, awns length, maturity, number of grains/spike, grain yield/spike, grain yield/meter, peduncle length, and ten grains length. Among these genotypes, ESWYT-136, ESWYT-104, and ESWYT-123 were observed beneficial for yield-related traits and are recommended for future cultivation breeding perspectives.

Keywords: Agro-morphological; Booting; Flowering; Grains/spike; Wheat genotypes

\section{Introduction}

Wheat (Tritium aestivum $\mathrm{L}$.) is a member of the grass family; Graminae and it has a dominant position in the agriculture sector also is essential food crop in the world, normally cultivated in the Rabi season, the tribe Triticeae, contains approximately 13-26 genera, 350 species, and it consisted of wheat 
(Triticum) and ryes (Secale) along with Aegilops, Agropyron, Eremopyron and Haynalidia [1]. The early classification systems were based on morphological characteristics. The true spikes of wheat, contain one to several sessile spikelets which are alternatively present on the opposite sides of the rachis. In 1753 Linnaeus first classified wheat. In 1918, Sakamura classified wheat into three groups based on chromosomes number. Diploids $14(\mathrm{n}=7)$, tetraploid $28(\mathrm{n}=14)$ and hexaploids $42(n=21)$ chromosomes. The major species of wheat are Triticum aestivum, Triticum durum, and Triticum compactum. It was estimated that the need for wheat started from 840 million tons to 1050 million tons, which is considered necessary to feed the growing population of the world [2]. About 600 million tons of wheat is cultivated on an annual basis and apart from rice and corn, wheat is considered to be the major product [3]. More than 40 countries cultivate the wheat crop annually to complete the requirement of food, which satisfies about $35 \%$ population of the globe.

About 14-million-acre land of Sindh is engaged in wheat production whereas 1.8-million-acre land produces two crops in a year. In the Sindh province of Pakistan, the wheat area is around 0.9 million hectares with production of 2.47 million tons and the average wheat yield was around $27 \mathrm{~kg} \mathrm{ha}{ }^{-1}[4]$. Planting at an inappropriate time may cause a drastic reduction in wheat yield. The sowing of the wheat crop in November produces the best yield and late sowing decreases the productivity of the seed index, tillers and grain yield. In Sindh, wheat breeders have developed varieties, which are suitable for cultivation in a wider range of environmental conditions [5].

The abiotic factors such as drought, salinity, water-logging, high temperature, and nutrient deficiency affect wheat crops and decrease wheat production in Pakistan. Drought is the main abiotic stress, which affects the growth and yield of wheat crops. The agromorphological traits such as tillers, grain yield, and harvest index, quality, and quantity of grains per spike are also affected due to drought and the grain filling period [6]. Salinity is major abiotic environmental stress, which affects wheat crop production, induces harmful effects on growth, and reduces the photosynthesis in wheat plants, germination percentage, and root length reduced due to salinity [7]. As the level of salts increases in the soil, the stem diameter and height of the plant are also reduced. Salinity weakened and reduced the grain yield, and harvest index of the wheat crop [8]. In Pakistan, water logging is the main problem that decreases the level of the nutrients nitrogen and increases the $\mathrm{Fe}$ and $\mathrm{Mn}$ nutrients in the soil. The frost damages can be reduced by late sowing of crop and the product can increase up to 2-3 folds higher than direct losses [9]. Potassium has a major role in the biochemical process of plants i-e., potassium activates the enzymes, synthesis of protein, and drought tolerance [10]. The yield losses occur if a shortage of potassium in the soil [11]. On the other hand, the best yield traits of wheat are selected for breeding programs and new varieties are formed, to increase wheat production. In many regions of the world, wheat production is increased by the replacement of modern wheat varieties [12], therefore; the assessment of the agromorphological variations in bread wheat genotypes under field conditions was kept under observations.

\section{Materials and Methods}

\section{Assessment of agro-morphological} diversity in bread wheat genotypes

The study was carried out to assess the agromorphological variations in seven wheat genotypes under field conditions at the Wheat Research Institute (WRI), Sakrand, Sindh, Pakistan. The randomized complete block design (RCBD) was used for the cultivation of seven wheat genotypes into three replications. Each genotype was cultivated in two rows. The row length was one meter and the space between the rows was $30 \mathrm{~cm}$. The experimental material consisted of seven wheat genotypes. The four wheat genotypes were obtained from the International Wheat and Maize Improvement Centre (CIMMYT), Mexico, two from Pakistan Atomic Energy Commission, 
Nuclear Institute of Agriculture (NIA) Tandojam, and one obtained from Wheat
Research Institute (WRI) Sakrand. The wheat genotypes detail is given in (Table 1).

Table 1. The detail of wheat genotypes cultivated at Wheat Research Institute (WRI) Sakrand-Sindh

\begin{tabular}{|c|c|c|c|c|}
\hline S. \# & Wheat genotypes & Pedigree/Parentage & Year & Breeding Institute \\
\hline $\mathbf{1}$ & ESWYT-136 & $\begin{array}{c}\text { GAN/AE. } \\
\text { SQUARROSA (897) }\end{array}$ & 2012 & $\begin{array}{c}\text { CIMMYT: (International Wheat and } \\
\text { Maize Improvement Centre) }\end{array}$ \\
\hline $\mathbf{2}$ & ESWYT-104 & YRSP/6 AOC & 2012 & CIMMYT \\
\hline $\mathbf{3}$ & ESWYT-107 & OPATAM 85 & 2012 & CIMMYT \\
\hline $\mathbf{4}$ & ESWYT-123 & AOC-YR/ATTILA & 2012 & CIMMYT \\
\hline $\mathbf{5}$ & SARANG & $\begin{array}{c}\text { SHA4/WEAVER//SKA } \\
\text { NZ2/SRMA }\end{array}$ & 2012 & $\begin{array}{c}\text { NIA: (Nuclear Institute of Agriculture, } \\
\text { Tandojam) }\end{array}$ \\
\hline $\mathbf{6}$ & SKD-1 & HD-2329 & 2006 & $\begin{array}{c}\text { WRI: (Wheat Research Institute, } \\
\text { Sakrand) }\end{array}$ \\
\hline $\mathbf{7}$ & SUNHERY & Cham4//URES/BOWS & 2010 & NIA \\
\hline
\end{tabular}

The data of the following agromorphological traits were recorded at the different growth stages of wheat

\section{Germination percentage ( $G \%$ )}

In all cultivated wheat genotypes, germination percentage was recorded by calculating the number of germinated seeds according to the formula.

\section{Days to heading (DH)}

The days for heading were counted from the $1^{\text {st }}$ day of sowing up to the time when $75 \%$ of heads were produced in the wheat crop.

\section{Days to maturity (DM)}

Days for maturity were recorded from the date of sowing up to the physical and physiological maturity of wheat genotypes.

\section{Grain filling period (GFP)}

The grain filling period of wheat genotypes was noted by subtracting the number of days to heading from the number of days to maturity.

\section{Tillers/plant (T/P)}

The number of tillers in each plant was counted from marked plants, as well as the number of functional tillers, were counted.

\section{Tillers/meter (T/m)}

The number of tillers per meter of all wheat genotypes were recorded and counted.

\section{Flag leaf area (FLA) $\left(\mathrm{cm}^{2}\right)$}

The flag leaf area of wheat genotypes was taken by multiplying the flag leaf length and flag leaf width area.

\section{Plant height (PH) (cm)}

The height of the plant was measured in centimeters at the time of maturity, from the base of the plant to the tip of the spike without awns, and data was recorded.

9. Spike length. (SL) (cm)

The spike length from base to tip without awns was measured in centimeters from the fertile tillers of tagged plants from each replication.

\section{Spikes/meters}

The number of spikes/meters in wheat genotypes were counted and recorded.

\section{Spikelets/spike (SPS)}

The number of spikelets each spike was counted and the average number of spikelets per spike from ten spikes were recorded.

\section{Grains/spike (GPS)}

The spikes of wheat genotypes were hand threshed and the average number of grains per spike from each plant were counted and recorded.

13. Hundred Grains weight (HGW) (g)

A hundred grains of each variety were counted and weighed by using digital balance and average grains weight was recorded.

14. Ten Grains length (TGL) (cm)

The ten grains length of each variety was measured in centimeters using a measuring scale. 


\section{Ten Grains width (TGW) (cm)}

The width of ten grains of wheat genotypes was measured in centimeters by foot scale.

\section{Harvest index $(\%)$}

Harvest index is the ratio of grain yield which was obtained from biological yield.

\section{Statistically analysis}

The basic statistics parameters such as; standard error, maximum, minimum, standard deviations, coefficient of variation for the agromorphological traits of wheat genotypes were calculated by using Microsoft excel 2013. The frequency distribution of agro-morphological traits of wheat genotypes was calculated using through online calculator www.frequencydistribution.com/ statistical package online. Analysis of variance (ANOVA) is the collection of statistical models. It is used to analyze the variations among and between group means and their related procedures. In the ANOVA setting, detected changes in a particular variable are divided into components attributable to different sources of variation. The data were statistically calculated in software statistics 8.1 version. The Pearson's coefficient correlation among the agromorphological traits of seven wheat genotypes were also observed. The mean comparative performances of the agro-morphological traits of wheat genotypes were measured through Duncan's Multiple Range Test (DMRT) and by using Microsoft excel 2013, which shows the variations among the traits.

\section{Results}

Assessment of basic statistics with the frequency distribution of agromorphological traits of seven bread wheat genotypes

The basic statistics and frequency distribution for germination percentage was recorded, which ranged from 53.33 to 94.29 , percentage with the mean value of $72.86 \pm 6.13$ and coefficient of variance was 0.22 presented in (Table 2), with the frequency distribution range was $61-88 \%$. The genotype ESWYT-123 showed minimum of $61.11 \%$ while; genotype SARANG indicated maximum 84.44 germination percentage. The days to booting were also calculated, which varied from 72 to 74 days with the mean value of $72.95 \pm 0.39$ and coefficient of variation was 0.01. The frequency distribution range for days to booting was 72-79 days. The genotype SUNHERY showed minimum of 70 days, while; genotype ESWYT-104 took maximum of 77 days for booting. The days to heading were recorded which were varied from 74.71 to 76.71 days with the mean value of $75.71 \pm 0.41$ and the co-efficient of variance was 0.01 . The frequency distribution range for days to heading was 72-84. The genotype SKD-1 took minimum of 72.66 days, while; genotype ESWYT-104 took 80.33. The days to flowering were varied from 80.14 to 82.43 days with the mean value of $81.29 \pm 0.44$ with the coefficient of variance was 0.01 . The frequency distribution range for days to flowering was 7988. The genotype ESWYT-136 took minimum of 79.33 days, while; genotype SKD-1 took 85.13 days for flowering. The days to maturity ranged from 115.86 to 117.86 days, with the mean value of $116.86 \pm 0.38$ and the coefficient of variance was 0.01 . The frequency distribution range for days to maturity was 113122 days. The genotype SKD-1 took minimum of 113 days, while; genotypes ESWYT-104 and ESWYT-107 took 118.5 days for maturity. The grain filling period ranged from 40.71 to 43.14 days with the mean value of $41.76 \pm 0.47$ and the co-efficient of variations was 0.03 . The frequency distribution range of the grain filling period was 40-46 days. The genotypes ESWYT-104, SKD-1 has taken minimum of 40 days, while; genotype SUNHERY took maximum of 44.33 days in the period of grain filling.

The tillers/plant ranged from 4.01 to 8.79 with the mean value of $6.07 \pm 0.70$, the co-efficient variance was 0.29 . The frequency distribution range was 5-8 with the minimum 5.44 number in ESWYT-136, while; maximum tillers 8 were present in the genotype SUNHERY. The tillers/meters varied from 26.43 to 59.29 with the mean value of $42.90 \pm 4.98$ and co-efficient of variance was 0.29 . The frequency distribution range was $40-51$ of tillers. In ESWYT-136, the minimum 33 tillers were 
present, while; maximum of 49.83 tillers/meters was counted in the genotype SUNHERY. The grains/spike ranged from 41.29 to 70.29 with the mean value of $54.02 \pm 4.42$ and the co-efficient of variance was 0.20 . The numbers of grains/spike were $40-70$ in SKD-1 that produced a minimum of 40.33 grains, while; genotype ESWYT-136 with maximum of 66.33 grains in the one spike were counted. It was noticed for grains yield/spike varied from 1.88 grams to 3.54 grams with mean value of $2.75 \pm 0.23$ and the co-efficient of variance was 0.21 . The grain yield/spike was 01-07 grams. In the SKD-1 minimum 1.92 grams, while; in genotype ESWYT-136 with maximum 3.53 grams, grain yield/spike. The grains/plant ranged from 146.14 to 414.71 with the mean value of $272.50 \pm 42.60$ and coefficient of variance was 0.39 . The frequency distribution range for grains/plants was 192330. The genotypes SKD-1 produced minimum of 192 and ESWYT-107 produced maximum of 326 numbers. The grain yield/plant was noted which varied from 5.05 to 20.51 with the mean value of $12.24 \pm 2.38$ and co-efficient of variance was 0.48 . The grain yield/plant was 8 17 in SKD-1 produced minimum of 8.44 grams, while; ESWYT-104 and ESWYT-123 produced maximum 14.19-grams grain yield/plant. The grain yield/meter also varied from 28.24 to 109.80 grams, with the mean value of $67.30 \pm 12.42$ and the co-efficient of variance was 0.48 . The frequency distribution range for grains yield/meter was 40-88gm the genotype ESWYT-123 produced minimum of 40.12 grams, while; in genotype SARANG maximum of $86.55 \mathrm{gm}$. The ten grains length varied from 6.21 to $7.01 \mathrm{~cm}$ with mean value of $6.60 \pm 0.12$ with the coefficient of variance being 0.04 . The ten grains length was $06-09 \mathrm{~cm}$ in the genotypes, ESWYT-107 in minimum $6.01 \mathrm{~cm}$ length was measured, while in SKD-1 maximum $8.01 \mathrm{~cm}$ ten grains length was measured. The ten grains width varied from 2.93 to $3.47 \mathrm{~cm}$ with the mean value of $3.19 \pm 0.09$ and the co-efficient of variance was 0.07 . The frequency distribution range of ten grains width was $03-06 \mathrm{~cm}$. In the genotypes, ESWYT-107 with minimum $3.01 \mathrm{~cm}$ width, while; in genotypes ESWYT-136 and SUNHERY found with maximum of $3.28 \mathrm{~cm}$ ten grains width.

The hundred-grain weight was varied from 3.85 to 5.25 grams with the mean value of $4.66 \pm 0.21$ with the coefficient of variance was 0.11 . The frequency distribution range for hundred grains weight was 4-7 grams. The genotype ESWYT-107 minimum 4.21 grams, while; in SUNHERY maximum 5.04 grams hundred-grain weight. The plant height varied from 83.71 to $97.57 \mathrm{~cm}$ with the mean value of $91.28 \pm 2.21$ and the co-efficient of variance was 0.06 . The frequency distribution range of plant height was found $77-101 \mathrm{~cm}$. SKD-1 minimum in $76 \mathrm{~cm}$, while; in ESWYT-104 maximum $97.06 \mathrm{~cm}$ plant height was recorded. The peduncle length, which was varied from 33.04 to $37.81 \mathrm{~cm}$ with the mean value of $35.59 \pm 0.79$ with the co-efficient of variance was 0.05 . The frequency distribution range for peduncle length was observed $32-41 \mathrm{~cm}$. ESWYT-104 minimum in $32.55 \mathrm{~cm}$ peduncle length, while; in genotype SUNHERY maximum at $38.33 \mathrm{~cm}$ peduncle length. The spike length varied from 10.71 to $13.06 \mathrm{~cm}$ with mean value of $11.66 \pm 0.37$ and the coefficient of variance was 0.08 . The frequency distribution range for spike length was $10-16 \mathrm{~cm}$. SKD-1 minimum at $10.50 \mathrm{~cm}$ spike length, while; ESWYT-107 the maximum $13.11 \mathrm{~cm}$ length was measured. The spikelets/spike varied from 14.86 to 18.57 spikelets with the mean value of $16.81 \pm 0.57$ with the co-efficient of variance was 0.08 . The frequency distribution range of spikelets/spike was 14-20. In the genotypes SKD-1 with minimum 14.78 spikelets, while; in genotype ESWYT-107 with maximum at 18.55 spikelets were counted. The awns length varied from 5.67 to $7.26 \mathrm{~cm}$ with the mean value of $6.62 \pm 0.25$ and the co-efficient of variance was 0.09 . The frequency distribution range of awns length was $5-11 \mathrm{~cm}$. ESWYT-136, the minimum length of $5.49 \mathrm{~cm}$ was noted, while; in SUNHERY the maximum length of $7.14 \mathrm{~cm}$ was measured. The basic statistics and frequency distribution for the flag leaf area were calculated. It varied from 29.38 to $46.13 \mathrm{~cm}$ squares flag leaf area with mean value 
of $38.92 \pm 2.88$ with the co-efficient of variance was 0.19 . The frequency distribution range for flag leaf area was found $32-47 \mathrm{~cm}$ squire. The minimum flag leaf area of $32.72 \mathrm{~cm}$ square was recorded in genotype ESWYT-104, while; the maximum $44.55 \mathrm{~cm}$ square flag leaf area was recorded for genotype SARANG.

The phenotypic correlation coefficient of quantitative traits of seven bread wheat genotypes

The days for heading indicated a negative and non-significant correlation to grain filling period, flag leaf area, peduncle length, tillers/plant, ten grains length, ten grains width, and 100 grains weight. Days for heading showed positive and non-significant correlation in days to maturity, spike length, plant height, awn length, spikelets/spike, grains/spike, tillers/meter, grain yield/m, grain yield/spike, grain yield/plant, and harvest index also detailed description shown in (Table 3). The grain filling period indicates the positive and non-significant correlation with flag leaf area, days to maturity, peduncle length, spike length, plant height, awns length, and grain yield/spike, spikelets number/spike, tillers/plant, grains/spike, ten grains width, and ten grains length, grain yield/meter, grain yield/plant and 100 grains weight. The grain filling period showed a negatively nonsignificant correlation with the number of tillers/meter and harvest index. Days for maturity showed a negative and non-significant correlation with ten grains length, flag leaf area, and harvest index. Whereas positive and significant correlation with plant height. The positive and non-significant correlation was noticed with peduncle length, spike and awns length, grain yield/plant number of spikelets/spike, grain yield/spike, grains/spike, tillers/meter, tillers/plant, grain yield/meter, and 100 grains weight. The flag leaf area $\left(\mathrm{cm}^{2}\right)$ indicates a negative and non-significant correlation with the number of tillers/meters, plant height, spike and awns length, grain yield/plant, and harvest index. The positive non-significant correlation was noticed with tillers number/plant, peduncle length, grain yield/meter, grain yield/spike grains number/spike, ten grains width, ten grains length, and 100 grains weight.

The plant height showed negative and nonsignificant correlation with tillers/meter, peduncle, harvest index, and ten grains length. Plant height indicates positively nonsignificant correlation with spike length, spikelets/spike, awns length, grains/spike, tillers/plant, grains yield/spike, grains yield/meter, ten grains width, grains yield/plant, and 100 grains weight. Peduncle length indicates positive and non-significant correlation with spikelets per spike length, grains/spike, awns length, tillers/plant, tillers/meter, ten grains width, gain yield/spike, grain yield/meter, and 100-grain weight. The peduncle length showed negative nonsignificant correlation with grain yield/plant, ten grains length, and harvest index. Spike length showed positive, non-significant correlation to spike length, awns length, spikelets/spike, ten grains width, grain yield/meter, grain yield/plant, grains number/spike, and grain yield/spike. Spike length indicates negative and non-significant correlation to ten grains length, number of tillers/plant, tillers/meter, harvest index, and 100 grains weight. The awns length showed positive, non-significant correlation with spikelets number/spike, tillers/meter, ten grains width, grain yield/meter, 100 grains weight, grain yield/plant, tillers number/plant, and harvest index. The awns length showed a negative non-significant correlation with grain yield/spike, grains number/spike, and 10 grains length. The spikelets/spike indicates the positive and non-significant correlation to grain yield/meter, grains number/spike, ten grains width, 100 grains weight, and grain yield/spike. The negative non-significant correlation was noticed with the number of tillers per plant, tillers/ per meter, 10 grains length, and harvest index. 
Table 2. Basic statistics and frequency distribution of agro-morphological traits of bread wheat genotypes

\begin{tabular}{|c|c|c|c|c|c|}
\hline Traits & Mean: SE & Max. & Min. & S.D & C.V \\
\hline Germination percentage & $72.86 \pm 6.13$ & 94.29 & 53.33 & 15.02 & 0.22 \\
\hline Days to booting & $72.95 \pm 0.39$ & 74.00 & 72.00 & 0.96 & 0.01 \\
\hline Days to flowering & $81.29 \pm 0.44$ & 82.43 & 80.14 & 1.09 & 0.01 \\
\hline Days to heading & $75.71 \pm 0.41$ & 76.71 & 74.71 & 1.00 & 0.01 \\
\hline Flag leaf area $\left(\mathrm{cm}^{2}\right)$ & $38.92 \pm 2.88$ & 46.13 & 29.38 & 7.05 & 0.19 \\
\hline Plant height $(\mathrm{cm})$ & $91.28 \pm 2.21$ & 97.57 & 83.71 & 0.52 & 0.06 \\
\hline Grain filling period & $41.76 \pm 0.47$ & 43.14 & 40.71 & 1.16 & 0.03 \\
\hline Days to maturity & $116.86 \pm 0.38$ & 117.86 & 115.86 & 0.92 & 0.01 \\
\hline Peduncle length $(\mathrm{cm})$ & $35.59 \pm 0.79$ & 37.81 & 33.04 & 1.95 & 0.05 \\
\hline Tillers per plant & $6.07 \pm 0.70$ & 8.79 & 4.01 & 1.70 & 0.29 \\
\hline Tillers per meter & $42.90 \pm 4.98$ & 59.29 & 26.43 & 12.20 & 0.29 \\
\hline Spike length $(\mathrm{cm})$ & $11.66 \pm 0.37$ & 13.06 & 10.71 & 0.90 & 0.08 \\
\hline Awns length $(\mathrm{cm})$ & $6.62 \pm 0.25$ & 7.26 & 5.67 & 0.16 & 0.09 \\
\hline Spikelets per spike $(\mathrm{cm})$ & $16.81 \pm 0.57$ & 18.57 & 14.86 & 1.40 & 0.08 \\
\hline Grains per spike & $54.02 \pm 4.42$ & 70.29 & 41.29 & 10.38 & 0.20 \\
\hline Grain yield per spike $(\mathrm{g})$ & $2.75 \pm 0.23$ & 3.54 & 1.88 & 0.58 & 0.21 \\
\hline Grains per plant & $272.50 \pm 42.60$ & 414.71 & 146.14 & 104.35 & 0.39 \\
\hline Grain yield per plant $(\mathrm{g})$ & $12.24 \pm 2.38$ & 20.51 & 5.05 & 5.82 & 0.38 \\
\hline Grain yield per meter $(\mathrm{g})$ & $67.30 \pm 12.42$ & 109.80 & 28.24 & 30.42 & 0.48 \\
\hline Hundred grains weight $(\mathrm{g})$ & $4.66 \pm 0.21$ & 5.25 & 3.85 & 0.52 & 0.11 \\
\hline Ten grains length $(\mathrm{cm})$ & $6.60 \pm 0.12$ & 7.01 & 6.21 & 0.30 & 0.04 \\
\hline Ten grains width $(\mathrm{cm})$ & $3.19 \pm 0.09$ & 3.47 & 2.93 & 0.21 & 0.07 \\
\hline Harvest index \% & $47.86 \pm 2.42$ & 50.31 & 46.13 & 5.92 & 0.34 \\
\hline
\end{tabular}

The grains/spike indicated a positively significant correlation with grain yield/ spike. The positive and non-significant correlation was noticed with ten grains width, grain yield/plant, grains yield/meter. The grains number/spike shows a negative non-significant correlation with tillers/plant, tillers/meter, ten grains length, harvest index, and 100 grains weight. The number of tillers/plants shows positive and significant correlation with the number of tillers/meters. The number of tillers/plant indicates the positive, nonsignificant correlation with grain yield/plant, 10 grains width, grain yield/meter, harvest index, and 100 grains weight. Tillers/plant shows the negative non-significant correlation, with, grain yield/ spike, 10 grains length. Several tillers/meters indicated the negative and non-significant correlation with ten grains length, grain yield/spike, ten grains width, grain yield/plant. Tillers/meter has shown a positive non-significant correlation with 100 grains weight, grain yield/meter, and harvest index. The ten grains width indicated the negative non-significant correlation with harvest index and ten grains length. The nonsignificant and positive correlation was noticed with the grain yield/meter, grain yield/plant, grain yield/spike, and 100-grain weight. The ten grains length showed a negative nonsignificant correlation with grain yield/spike, grain yield/meter, grain yield/plant, and positively non-significant correlation was noticed with 100 grains weight and harvest index.

The grain yield/meter indicated positive and non-significant correlation with grain yield/spike, 100 grains weight, and grain yield/plant. A negative non-significant correlation was found with the harvest index. Grain yield/spike showed positive nonsignificant correlation with 100 grains weight 
and grain yield/plant. The negative and nonsignificant correlation was observed with the harvest index. The grain yield/plant indicated positive and non-significant correlation with 100 grains weight and harvest index. The harvest index showed positively nonsignificant correlation with hundred grains weight. (Table 3), shows the Pearson's correlation coefficients among agromorphological traits of seven bread wheat genotypes.

Analysis of variance (ANOVA) of yield and yield associated traits of bread wheat genotypes.

The ANOVA for agro-morphological traits in seven bread wheat genotypes is indicated in (Table 4). Germination percentage mean square for genotypes was 229.274 and error was 211.261 that found with its non-significant differences at $\mathrm{p}-0.4236$. The days to booting were 15.1905 with the mean square for error was 1.3333 that shows highly significant differences at $\mathrm{p}-0.0002$. The mean square for days to flowering was 10.4921 and the error was 1.3016 with its significant differences at $\mathrm{p}$ 0.0012 . The days to heading were 22.6032 and the mean square for error was 2.0317 and highly significant $\mathrm{p}$-value of 0.0003 . The flag leaf area was 71.965 and error 55.311 with nonsignificant $p$-value of 0.3278 . The plant height was 443.980 and error 186.310 indicated nonsignificant $\mathrm{p}$-value of 0.0945 . The grain filling period was 6.04762 and error 2.16667 with non-significant differences at 0.0615 . The days to maturity were 10.6508 and the error was 0.9365 with highly significant differences at 0.0002 . The peduncle length was 11.5634 and error 2.8209 was found with significant differences at $\mathrm{p}-0.01$. The number of tillers/plant was 1.0330 and the error of 0.7740 which shows non-significant $\mathrm{p}$-value of 0.3149 . The number of tillers/meters was 135.270 and error 28.925 showed significant differences at $\mathrm{p}-0.011$. The spike length was 1.84597 and error 0.65622 indicated non-significant differences at $\mathrm{p}-0.0601$. The awns length was 1.16220 and error 0.11639 and highly significant differences were observed at p0.0004 . The spikelets/ spike was 4.51995 and error 1.65062 with non-significant differences at $\mathrm{p}-0.0649$. The number of grains/spike was 235.012 and error 82.982 indicated highly significant differences at $\mathrm{p}-0.00$. The grain yield/spike was 1.34975 and error 0.46512 with highly significant differences at p-0.000 recorded. The number of grains per plant was 6530.7 and error 4760.3 with a non-significant p-value of 0.3012 . The grain yield/plant was 20.7064 and an error of 20.7654 shows a nonsignificant $\mathrm{p}$-value was 0.4698 . The grains yield/meter was 2061.09 and error 1590.07 shows highly significant p-value of 0.000 . The hundred grains weight was 0.23887 and the error was 0.19664 has non-significant $p$-value of 0.3633 . The ten grains length 0.30040 and error 0.06665 show significant p-value of 0.01 . The ten grains width was 0.02798 and error 0.02923 shows non-significant differences at $p$ 0.4921 . The mean square of harvest index for genotypes was 12.2044 and the mean square for error was 15.4245 found with non-significant differences at p-0.5426, respectively.

\section{Duncan's Multiple Range Test (DMRT) of agro-morphological traits of seven bread wheat genotypes}

The mean comparison for germination percentage in wheat genotypes was studied, further described in (Table 5). The maximum 84.44 was noted in genotype SARANG and minimum of $61.11 \%$ was recorded for ESWYT-123. The days to booting mean comparison showed that ESWYT-104 took maximum of 77 days for booting and SKD-1, 71 days. The days to heading were recorded that ESWYT-104 took maximum of 80.33 and SUNHERY 73.33 days. The mean comparison for days to flowering was recorded with maximum of 84.33 days for SKD-1 and minimum 82 days in SUNHERY. The days to maturity for ESWYT-104, and ESWYT-107 took maximum of 118 days and SKD-1 minimum of 113 days. The grain filling period in SUNHERY took maximum 44.33 and ESWYT-104 and SKD-1 with 40 days. The mean comparison for tillers/plant counted in SKD-1, SARANG, and ESWYT-104 produced a maximum of $6.94,6.61$, and 6.33 tillers, while; ESWYT-136 and ESWYT-107 
produced minimum 5.67 number. The tillers/meters were calculated in SARANG and ESWYT-104 produced maximum of 48 tillers while ESWYT-136 minimum with 33, respectively.

Some grains/spikes counted in ESWYT-136 produced maximum number of 66 grains, while; genotype SKD-1 with minimum 40 . The grains yield/spike weighted in ESWYT-136 and ESWYT-107 produced maximum 3.53, and 3.16 grams, while; SKD-1 was found with minimum 1.66 grams, yield per spike. The number of grains/plant counted in ESWYT107 , that produced maximum number of 326 , while; SKD-1 with minimum 192 numbers. The grain yield per plant weighted in ESWYT104 and ESWYT-123 produced maximum 14.02 and 14.20 grams, while; SKD-1 with minimum 8.44 grams, grains yield/plant. The mean comparison for grain yield/meter was calculated among which the SUNHERY produced maximum 77.68 grams, while; ESWYT-123 produced minimum of 44.13 grams. The ten grains length was measured and the maximum length was $7.08 \mathrm{~cm}$ noted in SKD-1 and the minimum $6.80 \mathrm{~cm}$ length was recorded in ESWYT-136. The ten grains width measured and the maximum width $3.28 \mathrm{~cm}$ was calculated for ESWYT-136 and SUNHERY, while; the minimum width of $3.02 \mathrm{~cm}$ was recorded for SKD-1. The hundred grains weight calculated in the SUNHERY produced maximum 5.04 grams, while; ESWYT-107 with minimum 4.21 grams. The plant height was measured in the ESWYT-104 appeared with maximum in $97.66 \mathrm{~cm}$ height, while; SKD-1 with minimum $77.00 \mathrm{~cm}$. The peduncle length was measured with the maximum length of $38.33 \mathrm{~cm}$ was recorded in SUNHERY, while; minimum $32.55 \mathrm{~cm}$ in ESWYT-104. The mean comparison for spike length was measured amongst ESWYT-107 showed maximum $13.11 \mathrm{~cm}$ spike length, while; SKD-1 appeared with minimum $10.50 \mathrm{~cm}$. The awns length was noted in SARANG and SUNHERY maximum at $7.07,7.14 \mathrm{~cm}$, while; ESWYT-136 minimum at $5.49 \mathrm{~cm}$. Some spikelets/spikes were counted in ESWYT-107 that showed maximum number of 18 while SARANG minimum at 14 . The harvest index indicated the maximum 50.30 and $49.24 \%$ were recorded in ESWYT-104 and ESWYT-123. The genotypes ESWYT-107 and SKD-1 showed minimum of 46.13 and $46.17 \%$. The mean comparison for flag leaf area $\left(\mathrm{cm}^{2}\right)$ was calculated in the wheat genotypes. The genotype SARANG showed maximum $45.66 \mathrm{~cm}$ squares, while; genotype ESWYT104 indicated minimum of $32.72 \mathrm{~cm}$. 
Kalhoro et al.

Table 3. The phenotypic correlation coefficient of quantitative traits of seven bread wheat genotypes

\begin{tabular}{|c|c|c|c|c|c|c|c|c|c|c|c|c|c|c|c|c|c|c|c|}
\hline Traits & DH & GFP & DM & FLA & PH & PL & SL & $\mathbf{A L}$ & NSPS & NGPS & NTPP & NTPM & TGW & TGL & GYPM & GYPS & GYPP & HI & HGW \\
\hline & 1 & & & & & & & & & & & & & & & & & & \\
\hline GFP & $-0.39^{\mathrm{NS}}$ & 1 & & & & & & & & & & & & & & & & & \\
\hline DM & $0.70^{\mathrm{NS}}$ & $0.34^{\mathrm{NS}}$ & 1 & & & & & & & & & & & & & & & & \\
\hline FLA & $-0.48^{\mathrm{NS}}$ & $0.39^{\mathrm{NS}}$ & $-0.36^{\mathrm{NS}}$ & 1 & & & & & & & & & & & & & & & \\
\hline $\mathrm{PH}$ & $0.71^{\mathrm{NS}}$ & $0.29^{\mathrm{NS}}$ & $0.91^{\mathrm{s}}$ & $-0.03^{\mathrm{NS}}$ & 1 & & & & & & & & & & & & & & \\
\hline PL & $-0.38^{\mathrm{NS}}$ & $0.72^{\mathrm{NS}}$ & $0.11^{\mathrm{NS}}$ & $0.28^{\mathrm{NS}}$ & $-0.00^{\mathrm{NS}}$ & 1 & & & & & & & & & & & & & \\
\hline SL & $0.51^{\mathrm{NS}}$ & $0.37^{\mathrm{NS}}$ & $0.74^{\mathrm{NS}}$ & $-0.19^{\mathrm{NS}}$ & $0.63^{\mathrm{NS}}$ & $0.42^{\mathrm{NS}}$ & 1 & & & & & & & & & & & & \\
\hline $\mathrm{AL}$ & $0.31^{\mathrm{NS}}$ & $0.09^{\mathrm{NS}}$ & $0.46^{\mathrm{NS}}$ & $-0.35^{\mathrm{NS}}$ & $0.31^{\mathrm{NS}}$ & $0.37^{\mathrm{NS}}$ & $0.15^{\mathrm{NS}}$ & 1 & & & & & & & & & & & \\
\hline NSPS & $0.35^{\mathrm{NS}}$ & $0.38^{\mathrm{NS}}$ & $0.56^{\mathrm{NS}}$ & $0.22^{\mathrm{NS}}$ & $0.63^{\mathrm{NS}}$ & $0.45^{\mathrm{NS}}$ & $0.81^{\mathrm{NS}}$ & $0.12^{\mathrm{NS}}$ & 1 & & & & & & & & & & \\
\hline NGPS & $0.47^{\mathrm{NS}}$ & $0.35^{\mathrm{NS}}$ & $0.64^{\mathrm{NS}}$ & $0.16^{\mathrm{NS}}$ & $0.73^{\mathrm{NS}}$ & $0.14^{\mathrm{NS}}$ & $0.84^{\mathrm{NS}}$ & $-0.22^{\mathrm{NS}}$ & $0.83^{\mathrm{NS}}$ & 1 & & & & & & & & & \\
\hline NTPP & $-0.00^{\mathrm{NS}}$ & $0.33^{\mathrm{NS}}$ & $0.24^{\mathrm{NS}}$ & $0.13^{\mathrm{NS}}$ & $0.25^{\mathrm{NS}}$ & $0.39^{\mathrm{NS}}$ & $-0.14^{\mathrm{NS}}$ & $0.77^{\mathrm{NS}}$ & $-0.11^{\mathrm{NS}}$ & $-0.30^{\mathrm{NS}}$ & 1 & & & & & & & & \\
\hline NTPM & $0.12^{\mathrm{NS}}$ & $-0.10^{\mathrm{NS}}$ & $0.01^{\mathrm{NS}}$ & $-0.05^{\mathrm{NS}}$ & $-0.00^{\mathrm{NS}}$ & $0.19^{\mathrm{NS}}$ & $-0.26^{\mathrm{NS}}$ & $0.71^{\mathrm{NS}}$ & $-0.33^{\mathrm{NS}}$ & $-0.49^{\mathrm{NS}}$ & $0.87^{\mathrm{s}}$ & 1 & & & & & & & \\
\hline $10 \mathrm{GW}$ & $-0.09^{\mathrm{NS}}$ & $0.82^{\mathrm{NS}}$ & $0.55^{\mathrm{NS}}$ & $0.31^{\mathrm{NS}}$ & $0.60^{\mathrm{NS}}$ & $0.30^{\mathrm{NS}}$ & $0.32^{\mathrm{NS}}$ & $0.05^{\mathrm{NS}}$ & $0.44^{\mathrm{NS}}$ & $0.49^{\mathrm{NS}}$ & $0.21^{\mathrm{NS}}$ & $-0.29^{\mathrm{NS}}$ & 1 & & & & & & \\
\hline $10 \mathrm{GL}$ & $-0.79^{\mathrm{NS}}$ & $0.02^{\mathrm{NS}}$ & $-0.77^{\mathrm{NS}}$ & $0.35^{\mathrm{NS}}$ & $-0.71^{\mathrm{NS}}$ & $-0.22^{\mathrm{NS}}$ & $-0.77^{\mathrm{NS}}$ & $-0.58^{\mathrm{NS}}$ & $-0.73^{\mathrm{NS}}$ & $-0.56^{\mathrm{NS}}$ & $-0.15^{\mathrm{NS}}$ & $-0.12^{\mathrm{NS}}$ & $-0.10^{\mathrm{NS}}$ & 1 & & & & & \\
\hline GYPM & $0.34^{\mathrm{NS}}$ & $0.23^{\mathrm{NS}}$ & $0.34^{\mathrm{NS}}$ & $0.41^{\mathrm{NS}}$ & $0.52^{\mathrm{NS}}$ & $0.37^{\mathrm{NS}}$ & $0.32^{\mathrm{NS}}$ & $0.40^{\mathrm{NS}}$ & $0.39^{\mathrm{NS}}$ & $0.33^{\mathrm{NS}}$ & $0.64^{\mathrm{NS}}$ & $0.60^{\mathrm{NS}}$ & $0.12^{\mathrm{NS}}$ & $-0.45^{\mathrm{NS}}$ & 1 & & & & \\
\hline GYPS & $0.37^{\mathrm{NS}}$ & $0.43^{\mathrm{NS}}$ & $0.63^{\mathrm{NS}}$ & $0.17^{\mathrm{NS}}$ & $0.71^{\mathrm{NS}}$ & $0.09^{\mathrm{NS}}$ & $0.76^{\mathrm{NS}}$ & $-0.29^{\mathrm{NS}}$ & $0.78^{\mathrm{NS}}$ & $0.97^{\mathrm{s}}$ & $-0.36^{\mathrm{NS}}$ & $-0.62^{\mathrm{NS}}$ & $0.63^{\mathrm{NS}}$ & $-0.44^{\mathrm{NS}}$ & $0.16^{\mathrm{NS}}$ & 1 & & & \\
\hline GYPP & $0.62^{\mathrm{NS}}$ & $0.15^{\mathrm{NS}}$ & $0.84^{\mathrm{NS}}$ & $-0.34^{\mathrm{NS}}$ & $0.81^{\mathrm{NS}}$ & $-0.13^{\mathrm{NS}}$ & $0.48^{\mathrm{NS}}$ & $0.37^{\mathrm{NS}}$ & $0.51^{\mathrm{NS}}$ & $0.49^{\mathrm{NS}}$ & $0.04^{\mathrm{NS}}$ & $-0.22^{\mathrm{NS}}$ & $0.58^{\mathrm{NS}}$ & $-0.66^{\mathrm{NS}}$ & $0.00^{\mathrm{NS}}$ & $0.57^{\mathrm{NS}}$ & 1 & & \\
\hline $\mathrm{HI}$ & $0.11^{\mathrm{NS}}$ & $-0.72^{\mathrm{NS}}$ & $-0.26^{\mathrm{NS}}$ & $-0.69^{\mathrm{NS}}$ & $-0.42^{\mathrm{NS}}$ & $-0.62^{\mathrm{NS}}$ & $-0.52^{\mathrm{NS}}$ & $0.11^{\mathrm{NS}}$ & $-0.63^{\mathrm{NS}}$ & $-0.66^{\mathrm{NS}}$ & $0.20^{\mathrm{NS}}$ & $0.06^{\mathrm{NS}}$ & $-0.54^{\mathrm{NS}}$ & $0.17^{\mathrm{NS}}$ & $-0.65^{\mathrm{NS}}$ & $-0.60^{\mathrm{NS}}$ & $0.03^{\mathrm{NS}}$ & 1 & \\
\hline HGW & $-0.31^{\mathrm{NS}}$ & $0.63^{\mathrm{NS}}$ & $0.24^{\mathrm{NS}}$ & $0.32^{\mathrm{NS}}$ & $0.30^{\mathrm{NS}}$ & $0.27^{\mathrm{NS}}$ & $-0.19^{\mathrm{NS}}$ & $0.35^{\mathrm{NS}}$ & $0.07^{\mathrm{NS}}$ & $-0.09^{\mathrm{NS}}$ & $0.55^{\mathrm{NS}}$ & $0.11^{\mathrm{NS}}$ & $0.79^{\mathrm{NS}}$ & $0.10^{\mathrm{NS}}$ & $0.07^{\mathrm{NS}}$ & $0.06^{\mathrm{NS}}$ & $0.41^{\mathrm{NS}}$ & $0.21^{\mathrm{NS}}$ & 1 \\
\hline
\end{tabular}

Like; DH; Days to heading, GFP: Grain filling period, DM; Days to maturity, FLA; Flag leaf area $\mathrm{cm}^{2}$, PH; Plant height (cm), PL: Peduncle length (cm), SL: Spike length $(\mathrm{cm})$, AL; Awns length (cm), NSPS; Number of spikelets/spike, NGPS; Number of grains/spike, NTPP, Number of tillers/plant, NTPM, Number of tillers/meter, TGW, Ten grains width (cm), TGL, Ten grains length $(\mathrm{cm})$, GYPM, Grain yield/meter (g), GYPS, Grain yield/spike (g), GYPP, Grain yield/plant (g), HI, Harvest index\%, tHGW, Hundred grains weight (g) 
Table 4. Analysis of variance (ANOVA) for agro-morphological traits of seven bread wheat genotypes

\begin{tabular}{|c|c|c|c|c|c|}
\hline Source & Genotype & Replica & $\mathbf{F}$ & Error & $\mathbf{P}$ \\
\hline Germination \% & $229.274^{\mathrm{NS}}$ & 39.651 & 1.09 & 211.261 & 0.4236 \\
\hline Days to booting & $15.1905^{* *}$ & 1.0000 & 11.39 & 1.3333 & 0.0002 \\
\hline Days to flowering & $10.4921 * *$ & 1.8571 & 8.06 & 1.3016 & 0.0012 \\
\hline Days to heading & $22.6032 * *$ & 0.1429 & 11.12 & 2.0317 & 0.0003 \\
\hline Flag leaf area & $71.965^{\mathrm{NS}}$ & 156.089 & 1.30 & 55.313 & 0.3278 \\
\hline Plant height & $443.980^{\mathrm{NS}}$ & 57.173 & 2.38 & 186.310 & 0.0945 \\
\hline Grain filling period & $6.04762^{\mathrm{NS}}$ & 3.00000 & 2.79 & 2.16667 & 0.0615 \\
\hline Days to maturity & $10.6508 * *$ & 2.7143 & 11.37 & 0.9365 & 0.0002 \\
\hline Peduncle length & $11.5634^{*}$ & 13.1995 & 4.10 & 2.8209 & 0.0181 \\
\hline Tillers per plant & $1.0330^{\mathrm{NS}}$ & 14.1477 & 1.33 & 0.7740 & 0.3149 \\
\hline Tillers per meter & $135.270^{*}$ & 562.369 & 4.68 & 28.925 & 0.0112 \\
\hline Spike length & $1.84597^{\mathrm{NS}}$ & 1.45402 & 2.81 & 0.65622 & 0.0601 \\
\hline Awns length & $1.16220 * *$ & 0.88332 & 9.99 & 0.11639 & 0.0004 \\
\hline Spikelets per spike & $4.51995^{\mathrm{NS}}$ & 4.34246 & 2.74 & 1.65062 & 0.0649 \\
\hline Grains per spike & $235.012^{* *}$ & 149.190 & 2.83 & 82.982 & 0.000 \\
\hline Grain yield per spike & $1.34975^{\text {** }}$ & 1.76513 & 2.90 & 0.46512 & 0.000 \\
\hline Grains per plant & $6530.7^{\mathrm{NS}}$ & 19832.9 & 1.37 & 4760.3 & 0.3012 \\
\hline Grain yield per plant & $20.7064^{\mathrm{NS}}$ & 38.1012 & 1.00 & 20.7654 & 0.4698 \\
\hline Grain yield per meter & $2061.09^{* *}$ & 3258.65 & 1.30 & 1590.07 & 0.000 \\
\hline Hundred grain weight & $0.23887^{\mathrm{NS}}$ & 0.25680 & 1.21 & 0.19664 & 0.3633 \\
\hline Ten grains length & $0.30040^{*}$ & 0.07762 & 4.51 & 0.06665 & 0.001 \\
\hline Ten grains width & $0.02798^{\mathrm{NS}}$ & 0.04298 & 0.96 & 0.02923 & 0.4921 \\
\hline Harvest index \% & $7.33^{\mathrm{NS}}$ & 57.46 & 0.39 & 18.64 & 0.87 \\
\hline
\end{tabular}

$\mathrm{P}$-value $\geq 0.05$ is non-significant, $\mathrm{p}$-value at 0.01 to 0.05 is significant $*$ and p-value at 0.001 is highly significant $* *$ 
Table 5. The Duncan's Multiple Range Test (DMRT) of agro-morphological traits in seven bread wheat genotypes

\begin{tabular}{|c|c|c|c|c|c|c|c|}
\hline Traits & ESWYT 136 & ESWYT 104 & ESWYT 107 & ESWYT 123 & SARANG & SKD-1 & SUNHERY \\
\hline Germination percentage $\%$ & $63.333^{\mathrm{a}}$ & $63.333^{\mathrm{a}}$ & $74.443^{\mathrm{a}}$ & $77.780^{\mathrm{a}}$ & $84.443^{\mathrm{a}}$ & $82.223^{a}$ & $81.110^{\mathrm{a}}$ \\
\hline Days to booting & $72.333^{b}$ & $76.667^{\mathrm{a}}$ & $74.667^{\mathrm{a}}$ & $71.333^{\mathrm{b}}$ & $71.333^{\mathrm{b}}$ & $71.000^{\mathrm{b}}$ & $70.667^{b}$ \\
\hline Days to flowering & $79.333^{\mathrm{d}}$ & $80.333^{\mathrm{cd}}$ & $83.000^{\mathrm{ab}}$ & $80.333^{\text {cd }}$ & $79.667^{d}$ & $84.333^{\mathrm{a}}$ & $82.000^{\mathrm{bc}}$ \\
\hline Days to heading & $75.333^{b}$ & $80.333^{\mathrm{a}}$ & $78.333^{\mathrm{a}}$ & $74.333^{\mathrm{bc}}$ & $75.667^{b}$ & $73.627^{\mathrm{c}}$ & $73.333^{\mathrm{bc}}$ \\
\hline Flag leaf area $\mathrm{cm}^{2}$ & $44.500^{\mathrm{a}}$ & $32.723^{\mathrm{a}}$ & $35.253^{\mathrm{a}}$ & $35.150^{\mathrm{a}}$ & $45.657^{\mathrm{a}}$ & $39.120^{\mathrm{a}}$ & $40.067^{\mathrm{a}}$ \\
\hline Plant height $(\mathrm{cm})$ & $95.16^{\mathrm{ab}}$ & $97.57^{\mathrm{ab}}$ & $97.44^{\mathrm{ab}}$ & $89.27^{\mathrm{b}}$ & $93.88^{\mathrm{ab}}$ & $76.99^{\mathrm{b}}$ & $117.77^{\mathrm{a}}$ \\
\hline Grain filling period & $42.667^{\mathrm{a}}$ & $40.000^{\mathrm{b}}$ & $41.667^{\mathrm{ab}}$ & $42.000^{\mathrm{ab}}$ & $41.667^{\mathrm{ab}}$ & $40.000^{\mathrm{b}}$ & $44.000^{\mathrm{a}}$ \\
\hline Days to maturity & $117.00^{\mathrm{ab}}$ & $118.67^{\mathrm{a}}$ & $118.33^{\mathrm{a}}$ & $117.00^{\mathrm{ab}}$ & $116.33^{\mathrm{b}}$ & $113.00^{\mathrm{c}}$ & $117.67^{\mathrm{ab}}$ \\
\hline Peduncle length $(\mathrm{cm})$ & $34.497^{\mathrm{bc}}$ & $32.550^{\mathrm{c}}$ & $37.467^{\mathrm{ab}}$ & $35.327^{\mathrm{bc}}$ & $36.440^{\mathrm{ab}}$ & $34.657^{\mathrm{bc}}$ & $38.330^{\mathrm{a}}$ \\
\hline Number of tillers/plant & $5.5700^{\mathrm{a}}$ & $6.3300^{\mathrm{a}}$ & $5.5667^{\mathrm{a}}$ & $5.5867^{\mathrm{a}}$ & $6.6133^{\mathrm{a}}$ & $5.6000^{\mathrm{a}}$ & $6.9400^{\mathrm{a}}$ \\
\hline Number of tillers/meter & $33.000^{\mathrm{b}}$ & $48.333^{\mathrm{a}}$ & $41.167^{\mathrm{ab}}$ & $35.167^{\mathrm{b}}$ & $48.167^{\mathrm{a}}$ & $45.000^{\mathrm{a}}$ & $49.833^{\mathrm{a}}$ \\
\hline Spike length $(\mathrm{cm})$ & $11.940^{\mathrm{ab}}$ & $11.497^{\mathrm{bc}}$ & $13.103^{\mathrm{a}}$ & $11.497^{\mathrm{bc}}$ & $11.327^{\mathrm{bc}}$ & $10.493^{\mathrm{c}}$ & $11.730^{\mathrm{abc}}$ \\
\hline Awns length $(\mathrm{cm})$ & $5.4800^{\mathrm{b}}$ & $7.0233^{\mathrm{a}}$ & $6.8233^{\mathrm{a}}$ & $6.6833^{\mathrm{a}}$ & $7.0667^{\mathrm{a}}$ & $6.0300^{\mathrm{b}}$ & $7.1400^{\mathrm{a}}$ \\
\hline Number of spikelets/spike & $17.440^{\mathrm{ab}}$ & $15.883^{\mathrm{bc}}$ & $18.383^{\mathrm{a}}$ & $16.883^{\mathrm{abc}}$ & $17.773^{\mathrm{ab}}$ & $14.773^{\mathrm{c}}$ & $16.327^{\mathrm{abc}}$ \\
\hline Number of grains/spike & $66.333^{\mathrm{a}}$ & $52.333^{\mathrm{ab}}$ & $64.333^{\mathrm{a}}$ & $50.833^{\mathrm{ab}}$ & $53.333^{\mathrm{ab}}$ & $40.333^{\mathrm{b}}$ & $50.667^{\mathrm{ab}}$ \\
\hline Grain yield/spike (g) & $3.5300^{\mathrm{ab}}$ & $2.4167^{\mathrm{bc}}$ & $3.0367^{\mathrm{ab}}$ & $3.7067^{\mathrm{a}}$ & $2.5733^{\mathrm{abc}}$ & $1.7800^{\mathrm{c}}$ & $2.5767^{\mathrm{abc}}$ \\
\hline Number of grains/plant & $267.67^{\mathrm{ab}}$ & $319.83^{\mathrm{a}}$ & $326.17^{\mathrm{a}}$ & $297.17^{\mathrm{ab}}$ & $254.33^{\mathrm{ab}}$ & $192.00^{\mathrm{b}}$ & $250.17^{\mathrm{ab}}$ \\
\hline Grain yield/plant (g) & $11.727^{\mathrm{ab}}$ & $14.017^{\mathrm{ab}}$ & $12.627^{\mathrm{ab}}$ & $17.113^{\mathrm{a}}$ & $12.407^{\mathrm{ab}}$ & $8.437^{\mathrm{b}}$ & $11.647^{\mathrm{ab}}$ \\
\hline Grain yield/meter (g) & $66.36^{\mathrm{ab}}$ & $70.77^{\mathrm{ab}}$ & $74.76^{\mathrm{ab}}$ & $40.13^{b}$ & $124.37^{\mathrm{a}}$ & $54.86^{\mathrm{ab}}$ & $77.68^{\mathrm{ab}}$ \\
\hline Hundred grains weight (g) & $4.6467^{\mathrm{a}}$ & $4.5733^{\mathrm{a}}$ & $4.4800^{\mathrm{a}}$ & $4.9500^{\mathrm{a}}$ & $4.9267^{\mathrm{a}}$ & $4.2667^{\mathrm{a}}$ & $5.0300^{\mathrm{a}}$ \\
\hline Ten grains length $(\mathrm{cm})$ & $6.8000^{\mathrm{ab}}$ & $6.4000^{\mathrm{bc}}$ & $6.1000^{c}$ & $6.6333^{\mathrm{ab}}$ & $6.4500^{\mathrm{bc}}$ & $7.0833^{\mathrm{a}}$ & $6.7167^{\mathrm{ab}}$ \\
\hline Ten grains width $(\mathrm{cm})$ & $3.2833^{\mathrm{a}}$ & $3.1500^{\mathrm{a}}$ & $3.1333^{\mathrm{a}}$ & $3.2500^{\mathrm{a}}$ & $3.2000^{\mathrm{a}}$ & $3.0167^{\mathrm{a}}$ & $3.2833^{\mathrm{a}}$ \\
\hline Harvest index $\%$ & $48.23^{\mathrm{a}}$ & $50.31^{\mathrm{a}}$ & $46.13^{\mathrm{a}}$ & $49.26^{\mathrm{a}}$ & $47.64^{\mathrm{a}}$ & $46.17^{\mathrm{a}}$ & $47.17^{\mathrm{a}}$ \\
\hline
\end{tabular}




\section{Discussion}

The agro-morphological study of wheat is important for the enhancement of yield production thus; the present study was focused on the agro-morphology in seven bread wheat genotypes. The traits such as; G\%, DH, DB, DM, NTPP, NTP/m, PL, GYPP, GYPm, PH, SL, GPS and NGPP, TGL), HGW, SPS, TGW as described above were kept under observation during the growing season. The basic statistical parameters such as standard error (S.E), maximum, minimum, coefficient of variation $(\mathrm{C} . \mathrm{V})$, and standard deviation (S.D) were applied on collected data of agromorphological characters of seven wheat genotypes. The differences amongst the agromorphological characters of genotypes were recorded. The number of grains/plant showed the highest mean value 272.50. The lowest mean value 2.75 was recorded in grains yield/spike. The maximum 0.48 coefficient of variations were noted in grain yield/meter and the minimum 0.01 coefficient of variations were recorded in days for heading, days for flowering, and days for maturity. The number of grains/plant appeared with the highest 104.35 standard deviations and ten grains in minimum width 0.21 standard deviation. The same results have been reported by [13-15].

Duncan's multiple range tests were performed for the measured traits of tested wheat genotypes. The maximum germination percentage, $(84.44 \%)$ was noted in the genotype SARANG. The minimum $63.33 \%$ was recorded in ESWYT-136 and ESWYT104. The ESWYT-104 took maximum 77 days for days to booting and minimum 70.66 days for genotype SUNHERY. The maximum 84.33 days for flowering recorded in SKD-1 and minimum days for lowering were noted in ESWYT-136 and SARANG, $79.33 \& 79.66$ days respectively. The 118.33 days for maturity were recorded in genotypes ESWYT-104, ESWYT-107. A minimum of 113 days for maturity was observed in the genotype SKD-1. The maximum number of tillers/plant was recorded in the genotypes SUNHERY 6.94 tillers, genotype SARANG 6.61 tillers, and 6.33 tillers in ESWYT-104, and minimum 5.56 tillers/plants were noted in the genotypes ESWYT-136 and ESWYT-107. The maximum grain yield/spikes were produced by genotypes ESWYT-136, 3.53 grams and ESWYT-107, 3.16 grams, while; minimum yield was 1.78 grams noted in the genotype SKD-1. The maximum 326 grains number/plant was recorded in ESWYT-107 and the minimum number 192 grains/plant counted in the SKD-1 genotype. The genotype SUNHERY was calculated with the longest peduncle length 38.33 centimeters, while; genotype ESWYT104 was observed with the shortest peduncle length of 32.55 centimeters. The same results were described by [16-18].

A phenotypic correlation was calculated in all traits. Results indicated the number of grains/spike with positive and significant correlation to grain yield/spike (0.97). The days for maturity showed positive and significant correlation with plant height (0.91). The grain filling period indicated positive and nonsignificant correlation to days for maturity (0.34), awns length (0.09), spike length (0.37), grain yield/spike (0.43), tillers/plant (0.33), plant height (0.29), grain yield/meter (0.23), grains/spike (0.38), 10 grains length (0.02), hundred grains weight (0.63), 10 grains width (0.82), and flag leaf area (0.39). The flag leaf area found with positively non-significant correlation to grains/spike (0.16), peduncle length (0.28), spikelets/ spike (0.22), ten grains length (0.35), tillers/plant (0.13), ten grains width $(0.31)$, grain yield/spike $(0.17)$, grain yield/meter (0.41), and 100 grains weight (0.32). Plant height showed positively nonsignificant correlation with tillers/plant (0.25), spike length (0.63), grain yield/spike (0.71), awns length (0.31), grains/spike (0.37), grain yield/meter (0.52), ten grains width (0.60), and 100 grain weight $(0.30)$. The grain yield/spike indicated positively non-significant correlation to grain yield/plant $(0.57)$ and hundred grains weight (0.06). The ten grains length found in positive non-significant correlation with harvest index (0.17) and 100 grains weight (0.10). The grain yield/meter found with positive and non-significant correlation to grain yield/plant (0.00), grain yield/spike (0.16), and 
100 grains weight (0.07). The number of grains/spike calculated with negative and nonsignificant correlation to tillers/meter (-0.49), tillers/plant (-0.30), ten grains length $(-0.56)$, and harvest index (-0.66). The grain filling period observed negative and non-significant correlation with the harvest index $(-0.72)$ and the number of tillers/plants $(-0.10)$. The flag leaf area with negatively non-significant correlation to spike length (-0.19), plant height $(-0.03)$, grain yield/plant (-0.34), awns length ($0.35)$, tillers/meter $(-0.05)$, and harvest index (0.69). The plant height was found in a negatively non-significant correlation with ten grains length $(-0.71)$, peduncle length $(-0.00)$, tillers/meter (-0.00), and harvest index $(-0.42)$. The grain yield/meter found in negative nonsignificant correlation with the harvest index ($0.65)$. Grain yield/spike found with negative non-significant correlation to harvest index (0.60). Similar correlations were reported by [19-21].

Analysis of variances was carried out for agromorphological characters of wheat genotypes. The non-significant differences were recorded for germination percentage, grains filling period, tillers/plant, grain yield/plant, 100 grains weight, plant height, and spike length, spikelets per spike, and flag leaf area. Highly significant and significant variations were noticed for grains number/spike, grain yield/spike, grain yield/ meter, number of tillers/meter, days to booting, days for heading, peduncle length, and days for flowering, awns length, and ten grains length. The same findings were reported by $[22,23]$.

\section{Conclusion and Recommendations}

It is concluded from this study that genotypes ESWYT-136, ESWYT-104, ESWYT-123, and SKD-1 were morphologically different from each other and are recommended for breeding programs and cultivation.

\section{Authors' contributions}

The experiments performed: AA Kalhoro. The experiments were conceived and designated: HB Bozdar \& HA Sahito. Data analyzed: T Kousar \& MA Korai. Materials/ tools/ analysis: WM Mangrio.

\section{Acknowledgment}

The authors are highly thankful for the sample collection points, Wheat and Maize Improvement Centre Mexico, from which four, Nuclear Institute of Agriculture Tandojam from which two and Wheat Research Institute Sakrand farm which one bread wheat genotypes samples were collected, respectively. Again all co-authors of this valuable research paper are cheerfully pleased for corresponding of this paper, Dr. Hakim Ali Sahito for their restless admiral approaches and expertise which poured the soul of encouragement and hope amongst us. His revolutionary ideas lead us on the leading pathway by which we have reached this attempt.

\section{References}

1. Simmonds NW (1976). Principles of crop improvement. Longman science and technology New York 1-408.

2. Rosegrant MW, Agcaoili-Sombilla A \& Perez N (1995). Global Food Projections to 2020. Implications for Investment, Food, Agriculture and the Environment. Discussion paper 5. Washington, D.C IFPRI 1-54.

3. Feldman MJ, Smartt J \& Simmonds NW (1995). Wheat. In: eds. Evolution of crop plants. Harlow, UK: Longman Scientific and Technical 185-192.

4. Ansari AH, Khushk AM, Sethar MA, Arian AN \& Memon MY (1989). Effect of sowing dates on the growth and yield of wheat cultivars. Pak. J of Sci and Indus Res 32(1):3942.

5. Anwar JS, Khan B, Rasul I, Zulkiffal M \& Hussain M (2007). Effect of sowing dates on yield and yield components in wheat using stability analysis. Int J of Agric Biol 9(1):129-132.

6. Royo C, Abaza M, Blanko R \& Garcia Del Moral LF (2000). Triticale grain growth and morphometry as affected by drought stress, late sowing and simulated drought stress. Aust J of Plant Physiol 27: 10511059.

7. Agnihotri RK, Palni LMS \& Pandey V (2006). Screening of landraces of rice 
under cultivation in Kumaun Himalayan for salinity stress during germination and early seedling growth. Indian $J$ of Plant Physiol 11(30): 262-272.

8. Francios LE, Mass EV, Donovon TJ \& Young VL (1986). Effect of salinity on grain yield, quality, vegetative growth and germination of semi-dwarf and durum wheat. Agron J 78(6): 1053-1058.

9. Fuller MP, Fuller AM, Kaniouras S Christophers J \& Fredericks T (2007). The freezing characteristics of wheat at ear emergence. European J of Agron 26: 435441.

10. Marschner H (1995). Mineral nutrition of higher plants. Academic press Inc San DiegoUSA 148-73.

11. Ali S, Sayed JAS, Khalil Hidayat R, Maqbool K \& Waseem U (2008). Partial resistance to yellow rust in introduced winter wheat germplasm at the north of Pakistan. Austral J of Crop Sci 3(1): 3743.

12. Davood AF, Ashkboos M, Sadeghi M \& Bahram DN (2004). Evaluation of salinity tolerance in landrace wheat germplasms of Cereals Research Collection Department. Isfahan Agri and Nat Reso Res Center, Isfahan, Iran 14.

13. Maggs Kölling GL, Madsen S \& Christiansen JL (2000). A phenetic analysis of morphological variation in Citrullus lanatus in Namibia. Genet Resour Crop E 47: 385-393.

14. Shakhatreh Y, Haddad N, Alrababah M, Grando S \& Ceccarelli (2010). Phenotypic diversity in wild barley (Hordeum vulgare L. ssp. spontaneum (C. Koch) Thell.) accessions collected in Jordan. Genet Resour Crop E 57:131146.

15. Aghaee M, Reza M \& Sadegh N (2010). Agro-morphological characterization of durum wheat accessions using pattern analysis. Aust J of Crop Sci 4(7):505-514.

16. Ashfaq M, Khan AS \& Ali Z (2003). Studied the association of morphological traits with grain yield in wheat (Triticum aestivum L.). Int J Agri of Biol 5: 15608530.

17. Saleem U, Khaliq I, Mahmood $\mathrm{T}$ \& Rafique M (2006). Phenotypic and genotypic correlation coefficients between yield and yield components in wheat. Japan Agri Rese 44(1):1-8.

18. Nawaz R, Inamullah A, Habib D, Siraj \& Muhammad SI (2013). Agromorphological studies of local wheat varieties for variability and their association with yield-related traits. Pak $J$ Bot 45(5): 1701-1706.

19. Gholamin R, Khayatnezhad M, Jamaati-eSomarin S \& Zabihi-e-Mahmoodabad R (2010). Effects of polyethylene glycol and $\mathrm{NaCl}$ stress on two cultivars of wheat (Triticum durum) at germination and early seedling stages. American- Eurasian J of Agric and Environ Sci 9(1):86-90.

20. Khan MM, Khan RD, Qasim M \& Rabani MA (2007). Evaluation of some wheat (Triticum aestivum L.) germplasms for its variability for different traits. Gomal Uni J of Res Sci 23(2): 32-38.

21. Mohibullah M, Rabbani MA Jehan S, Zakiullah, Amin A \& Ghazanfarullah (2011). Genetic Variability and Correlation analysis of bread Wheat (Triticum aestivum L.) Accessions. Pak J Bot 43(6): 2717-2720.

22. Fakhfak M, Daaloul A, Rezgui S \& Yahyaoui A (19998). Evaluation des association's entre le rendement en grain etles caractères morpho- physiologiques chezle blé dur dans les régions semiarides. Revue de l' l'Institut National Agronomique de Tunisie. 13(2): 43-51.

23. Gashaw A, Mohammed $\mathrm{H}$ \& Singh $\mathrm{H}$ (2007). Selection criterion for improved grain yields in Ethiopian durum wheat genotypes. Afric Crop Sci J 15: 25-31. 